\title{
EDUCATION AND RESEARCH ENHANCEMENT IN LAND ADMINISTRATION SECTOR AT KATHMANDU UNIVERSITY
}

\author{
Mr. Subash Ghimire
}

Keywords: Education, Research, Land Administration, Kathmandu University

\begin{abstract}
This paper aims to strengthen the existing education and research in Land Administration and draw attention of all national and international Land Administration community for their contributions to promote education and research in Land Administration in developing countries such as Nepal. This paper also deals with the challenges and opportunities in collaborative efforts made by KU and LMTC to become a leader in this sector. The cost effective and reliable information is necessary for effective public service delivery. The economic growth of any country involves the effective service delivery. This requires highly skilled and knowledgeable human resources and output oriented research. To make land administration education, a leader course in Nepal and also within the region in the future, KU has to overcome many challenges. Some challenges may be addressed in the national level but some require collaborations and cooperation from international level. Finally, Education and research in Land Administration sector helps to develop quality land administrational professionals which in turn may incorporate the entire South Asia region as a potential Land Administration market. $K U$ is committed to develop a centre of excellence in Land Administration sector by providing quality education and research.
\end{abstract}

\section{INTRODUCTION:}

Land Administration is a discipline that integrates different land issues from different disciplines such as legal, social, economic, technical, planning, management and so on. The strengthening of Land administration system is at high agenda of Nepal government.The sufficient number of efficient land professionals is required to fulfil this mission. However, there exist major gaps in providing education in all other aspects of land administration and management. Moreover, in the scenario of federalism of the state, the country needs to develop strong land professionals. It is very important to develop land professionals for the effective implementation of recently formulated land use policy. It is well known fact that today the Geomatics and Land Administration field has become very important as it is the program which deals with land. In context of Nepal, land issues are very critical and service delivery in land is poor. Therefore, the production of qualified human resources in this field is very important. Besides understanding the need of higher education in the land administration sectors due to lack of skilled and professional human resources, there is necessity to conduct joint program for enhancing research and education in land administration sector.

Several Universities in United States, Europe and India are offering courses in Land Administration, Surveying, mapping and Geomatics Engineering. In this context, Land Management Training Center (LMTC) and Kathmandu University(KU) have already started the BE Geomatics Engineering in 2007 and successfully running under the framework of Memorandum of understanding (MOU). KU and LMTC also share the physical boundary and resources to promote Geomatics Engineering and Land Administration courses. This course supports the further strengthening of the collaboration between KU and LMTC.

Kathmandu University (KU) was established in November 1991 as an autonomous, non for profit, non-government, dedicated to maintain high standards of academic excellence, public institution through private initiative. The university is committed to develop leaders in professional areas through quality education with the vision "To become a World Class University devoted to bringing knowledge and technology to the service of mankind". It is committed not only to develop leaders in professional areas through quality education but also develop as a centre of excellence. Long term presence of the university is also intended to benefit the local communities in terms of development of small scale business and community services.

Under the University there are seven schools: School of Engineering, School of Management, School of Science, School of Arts, School of Medical Sciences, School of Education and School of Law. Departments are headed by school. Currently, Geomatics Engineering lies under the Department of 
Civil and Geomatics Engineering within the umbrella of School of Engineering of Kathmandu University.

Mainly LMTC under the Ministry of Land Reform and Management is established to produce the skilful surveying, mapping and land administration and management professionals through trainings within the country. LMTC is offering two types of regular courses and several short courses; Basic Survey course and Senior and Junior Survey course. Similarly, School of Geomatics which was established in 1999 in affiliation to council for technical education and training (CTEVT) is a private institution providing education in the field of surveying and mapping. Since its establishment, the school has been working at human resource development in the field of surveying and spatial information application at different levels. It is offering Diploma in Survey Engineering, TSLC in Survey Engineering (surveyor), and Short term and tailored made course on surveying/mapping, GIS, GPS and Land Information-system.

\section{OBJECTIVES OF GEOMATICS PROGRAM:}

The main objectives of Geomatics program at KU are as follows

- To produce undergraduate and graduate level highly skilled andqualified professionals in the field of land Administration and management.

- To conduct and promote research and development activities in the field of land administration/ management.

\section{STATUS OF UNDERGRADUATE GEOMATICS ENGINEERING:}

The undergraduate Geomatics engineering program was started in August 2007. Total 102 students are graduated as Geomatics Engineers and most of them are already employed in various government and non-government institutions.

The first MOU between KU and LMTC under the framework of which, the Geomatics program had been started was completed in 2011 and a second MOU is completed with the intake of 2014 batch. Under first completed MOU, Ministry of Land Reforms and Management have provided financial support for 7 years for four batches. In this case $75 \%$ of total fee is waived for 24 students. Similarly, under the framework of second MoU, the 2011, 2012, 2013 and 2014 batch students are enrolled in the course. The Ministry of Land Reform and Management is providing scholarships under various categories to number of students. In the new MOU, a $100 \%$ tuition fee is waived for two students from government employee in the engineering services under survey group category, a $50 \%$ fee is waived for eight students from four Development Regions except the central regions of Nepal and 33\% of tuition fee is waived for 10 students passing the Kathmandu University Common Admission Test (KU-CAT) entrance exam on merit basis.

\section{EXISTING PHYSICAL FACILITIES:}

The library facilities and sports facilities are available at KU and LMTC. The survey equipments, computer lab for remote Sensing and Geodesy are available at LMTC. Similarly, computer Lab for computer programming, GIS lab and conference lab for provision for e-learning are available at KU. The course syllabus of BE Geomatics Engineering program is consistently revised by the Subject Committee/Faculty board and academic council of $\mathrm{KU}$ with due consideration of feedback from students and stakeholders including industries every year. This engineering program have strong component of field survey training equivalent to 4.5 months in 4 years program and internship of one and half months.

\section{GRADUATE PROGRAM IN LAND ADMINISTRATION:}

$\mathrm{KU}$ has also started two year's master degree program in 2013 in Land Administration in collaboration with LMTC and is successfully running at KU. The main aim of starting the master in land Administration course is to produce graduate level highly skilled and qualified professionals in the field of land Administration and to conduct and promote research and development activities in the field of land administration and management. The market study was carried out in 2010 and implementation plan was drafted in 2011 to start the master program. Land administration program at KU consists of multidisciplinary courses so that the intake will be from multidisciplinary background. The Government of Nepal has approved $100 \%$ scholarship to 10 candidates for government employee up to four batches. The financial aid is also available to selective full paying students in the form of graduate teaching assistantships as per the requirement of the Department.

The 2013 batch students are in final semester and are carrying out the Master research focussing on various land issues. The Memorandum of Understanding (MOU) between Kathmandu University, School of Engineering, Nepal and University of Twente, Faculty of Geo-Information Science and Earth Observation, the Netherlands had alreadybeen signed to run the Land Administration program.

\section{RESEARCH ENHANCEMENT:}

$\mathrm{KU}$ has given priority in the following areas of research in Geomatics Engineering. They are remote sensing, digital image processing, Geographic Information System, physical Geodesy, Photogrammetry: Analytical, Digital and Closs 
Range, GPS Surveys: Static, Differential and Real Time, Computer Cartography, Mobile Mapping, Land Administration and management. In this context, KU has carrying out the research project titled Strengthening Geospatial Capacity building at Kathmandu University in collaboration with ICIMOD and includes following activities.

Activity1: Extending exchange program and internship opportunities on five selected projects and publishing story map through ArcGIS online. This activity is successfully completed.

Activity2: Development of geo-enabled web and mobile applications and services through a consortium of likeminded department, centres and institutions (Web-GIS based disaster impact and need assessment)

Activity3: Advance research using remote sensing data (Burnt Area Mapping Automation for the Landsat Using Python)

Similarly, the Geomatics Engineering program is also carrying out the next project in collaboration with ICIMOD titled Estimation of above ground forest biomass and carbon stock using UAV images. In collaboration with OXFAM, Geomatics Engineering program successfully completed project on hydro - geological mapping of aquifers.

\section{PROSPECTS OF THE PROGRAM:}

KU has set vision for Geomatics program "To become centre of excellence by providing quality education and research for leadership in the Land sector with joint cooperation with government and other collaborating organisations"

Therefore, vision is categorized into short term and long term. The short term vision is to continue the Geomatics Program with quality output. The long term vision was to head towards research oriented Master and $\mathrm{PhD}$ courses. Geomatics Engineering program in KU and LMTC has set following future plan to fulfil its vision:

- To start Diploma in Geomatics Engineering to produce operational level skilled human resources.

- To start B. Tech (Ed) in Surveying.

- To start MS by research in Land Administration and management.

- To enrol more $\mathrm{PhD}$ candidates in the field of Land administration and management.

- To emphasize the research projects in Land Administration and management.

- To strengthen and develop the intern opportunity for Geomatics Engineering students in related industries.

- To establish Geo Spatial Lab.
- To Establish CORS station within $\mathrm{KU}$ in collaboration with University of Tokyo.

- To carry out more research projects in collaboration with collaborating organisations.

\section{MAJOR CHALLENGES:}

The major challenges of undergraduate Geomatics Engineering and Master Program in Land Administration in Kathmandu University are highlighted as follows.

- Infrastructure development

- Physical facilities

- Hardware and software

- Delivery of course

- Faculty expansion Visiting experts (national/international)

Transfer of LMTC officials

- Knowledge exchange programs

- Enhancing private/ private and private/ public understanding and support at both national and international level for running the program.

- Expansion of further higher education and job market .

- Sustainability of the program.

\section{OPPORTUNITIES:}

There is an ample of opportunities for KU to become a centre of excellence in Land Administration Sector. Institutions like UT/ITC, ICIMOD, private and government agencies are willing to support $\mathrm{KU}$ to achieve its goal. KU has expectations for expert advice from national and international land administration community.

\section{CONCLUSION:}

The land issues are critical and service delivery in land is poor in many developing countries. Therefore, development of qualified human resources in the field of Land Administration and management become necessary. Land administration and Geomatics Engineering has become emerging field as it directly deals with surveying, mapping and land management. KU in collaboration with LMTC is playing crucial role for it. To become a centre of excellence in Nepal and also within the region in the future, KU has to grab the opportunities and overcome the challenges. Some of the above mentioned challenges could be addressed in national level but some requires cooperation and collaboration from the international level. Therefore, it is essential to draw attention of all national and international land administration and management community for their contributions to promote education and research in land administration sector in developing countries such as Nepal. 


\section{References:}

Bhattarai, N. (2009) Geomatics Engineering Education in Kathmandu University: Issues and Challenges, 7th FIG Regional Conference Spatial Data Serving People: Land Governance and the Environment - Building the Capacity Hanoi, Vietnam, 19-22 October.

Ghimire, S., Maskey, R. K. \& Joshi J.R (2013) Developing A Centre of Excellence in Geomatics and Land Administration Sectors at Kathmandu University, proceeding of International Workshop on Advanced Geospatial Technologies for Sustainable Environment and Culture-2013 (as an event of ISPRS, Technical commission VI, Education and Outreach, Working Group 6) held in Pokhara, Nepal from 12-13 September, 2013.

Ghimire, S. (2011) The role of Geomatics engineering education for national development. Proceeding of the 2011 International Symposium on Advanced Engineering, Busan, Korea

Ghimire, S. (2011) KU Courts Communities, the Kathmandu Post, Volume XIX No.171.

KU \& LMTC (2011) Proposal for funding to Geomatics Engineering, proposal submitted to MOLRM.

KU \& LMTC (2011) Memorandum of Understanding signed between KU and LMTC

KU (2013) Geomatics Engineering brochure, Published by Department of Civil and Geomatics Engineering.

Tempfli, K. (2008) An Academic Vision on the BE in Geomatics Course, paper presented on workshop (November 19-23) on Curriculum development for BE Geomatics Engineering, Kathmandu University.

URL1: http//www.ku.edu.np/, accessed on March 15, 2015.

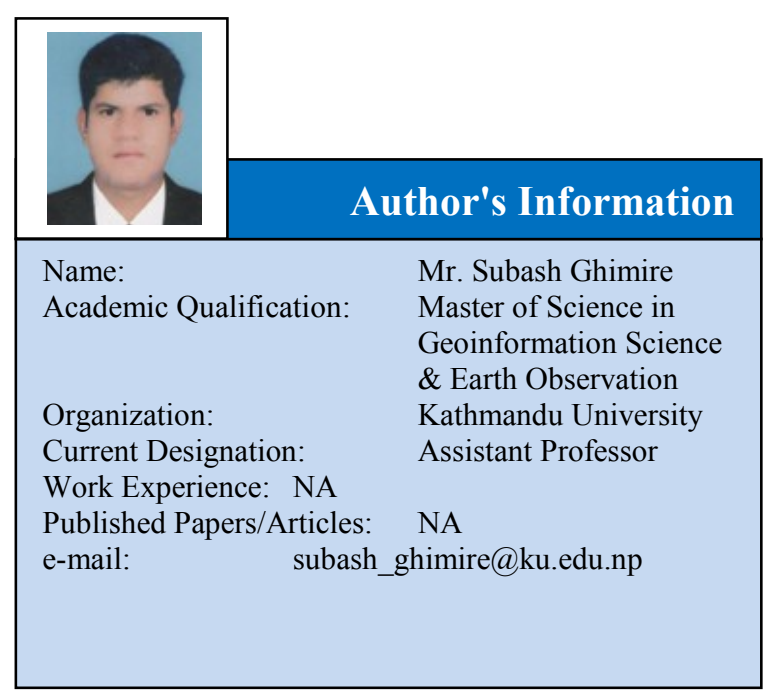

Mr. Subash Ghimire \& Earth Observation Kathmandu University

Current Designation:

Published Papers/Articles: NA

-mail: subash_ghimire@ku.edu.np 